\title{
Macro level factors influencing strategic responses to emergent pandemics: A scoping review
}

\author{
Nina J Zhu' ${ }^{1}$, Ewan B Ferlie ${ }^{2}$, \\ Enrique Castro-Sánchez ${ }^{3}$, \\ Gabriel Birgand ${ }^{1}$, Alison $\mathrm{H}$ \\ Holmes ${ }^{1}$, Rifat A Atun ${ }^{4}$, Hailey \\ Kieltyka ${ }^{5}$, Raheelah Ahmad ${ }^{1,5,6}$; \\ the COMPASS (COntrol and \\ Management of PAndemicS \\ through Strategic analysis) \\ study group
}

\footnotetext{
${ }^{1}$ National Institute for Health Research Health Protection Research Unit in Healthcare Associated Infection and Antimicrobial Resistance at Imperial College, London, UK

${ }^{2}$ King's Business School, King's College London, London, UK

${ }^{3}$ Division of Nursing, School of Health Sciences, City, University of London, London, UK

${ }^{4}$ Department of Global Health and Population, Harvard T. H. Chan School of Public Health, Boston, MA, USA ${ }^{5}$ Division of Health Services Research and Management, School of Health Sciences, University of London, London, UK ${ }^{6}$ Institute of Business \& Health Management, Dow University of health Sciences, Karachi, Pakistan
}

\section{Correspondence to:}

Dr Raheelah Ahmad Division of Health Services School of Health Sciences City, University of London Northampton Square London EC1V 0HB UK

KRaheelah.Ahmad@city.ac.uk
Background Strategic planning is critical for successful pandemic management. This study aimed to identify and review the scope and analytic depth of situation analyses conducted to understand their utility, and capture the documented macro-level factors impacting pandemic management.

Methods To synthesise this disparate body of literature, we adopted a two-step search and review process. A systematic search of the literature was conducted to identify all studies since 2000 , that have 1 ) employed a situation analysis; and 2) examined contextual factors influencing pandemic management. The included studies are analysed using a seven-domain systems approach from the discipline of strategic management.

Results Nineteen studies were included in the final review ranging from single country (6) to regional, multi-country studies (13). Fourteen studies had a single disease focus, with 5 studies evaluating responses to one or more of COVID-19, Severe Acute Respiratory Syndrome (SARS), Middle East Respiratory Syndrome (MERS), Influenza A (H1N1), Ebola virus disease, and Zika virus disease pandemics. Six studies examined a single domain from political, economic, sociological, technological, ecological or wider industry (PESTELI), 5 studies examined two to four domains, and 8 studies examined five or more domains. Methods employed were predominantly literature reviews. The recommendations focus predominantly on addressing inhibitors in the sociological and technological domains with few recommendations articulated in the political domain. Overall, the legislative domain is least represented.

Conclusions Ex-post analysis using the seven-domain strategic management framework provides further opportunities for a planned systematic response to pandemics which remains critical as the current COVID-19 pandemic evolves.

The current SARS-CoV-2 (COVID-19) pandemic has brought into sharp focus the readiness and capacities of health and wider systems in the ability to respond and protect the public [1,2]. Real-time situational analyses [3] are essential as the pandemic evolves, but this learning must build on what is already known from (albeit smaller scale) pandemics, and the role of important wider environmental factors which contributed to control or conversely were found to have delayed an adequate response. Assessment of the environment or situational analyses in health planning and emergency responses are fundamental for effective design and revision of national level policies and implementation of plans based on these. The scope and content of such analyses, of course, must include basic underlying demographic, 
epidemiological and health metrics of the population, but also factors on the 'supply-side' which should account for the wider infrastructure, including technological capabilities. In the case of infectious diseases, analyses must also include the prevailing social norms and cultural context, which may pose additional risks to spread, with an understanding informing which interventions are most appropriate for breaking the chain of transmission [4]. During infectious disease outbreaks, advancements in surveillance, monitoring and modelling have enabled early warning systems and communications via the World Health Organisation (WHO), the Africa Centres for Disease Control and Prevention (Africa CDC), the European Centre for Disease Prevention and Control (ECDC), the US Centers for Disease Control and Prevention (CDC), and others. Together, they form the mechanisms for alerting the global community as outbreaks evolve to an epidemic or pandemic [57]. But in addition to these 'situation reports' (i.e. what is happening in terms of the disease transmission and its impact), and ideally before the emergence of a pandemic, what do we know about the capacity of a given country to respond? And how do we assess the wider contextual influences which are particularly relevant in a pandemic scenario where advanced health systems and national economies are not enough to ensure successful containment $[8,9]$ ?

Our recent work on what can be described as the ever-present pandemic threat of antimicrobial resistance, has suggested the PESTELI framework [10], which draws attention to the following environmental domains: Political factors, Economic influences, Sociological trends, Technological innovations, Ecological factors, Legislative requirements and Industry analysis [11]. These are more fully defined in Table 1.

Table 1. Definition of PESTELI domains

\begin{tabular}{lll} 
DomaIN & DEFINITION & EXAMPLES \\
Political (P) & Political commitment, political leadership, political transparency & $\begin{array}{l}\text { National guidelines and policies, governance } \\
\text { committee; accountability; corruption }\end{array}$ \\
\hline Economic (Econ) & $\begin{array}{l}\text { Wider economic influences which have a bearing on the health system or on } \\
\text { individuals and organisations }\end{array}$ & Funding sources and channels \\
\hline Sociological (S) & $\begin{array}{l}\text { Relevant trends according to age, gender, the way people live, work, } \\
\text { norms and behaviours. Also include factors about how professionals in } \\
\text { organisations behave }\end{array}$ & Culture, religion, education, population composition \\
\hline Technological (T) & New approaches to the surveillance, diagnosis or treatment of infections & Surveillance, diagnosis, pathogen discovery \\
\hline Ecological (E) & $\begin{array}{l}\text { The epidemiology of other infections and trends in human health, animal } \\
\text { health, agricultural factors, climate }\end{array}$ & $\begin{array}{l}\text { Pollution, agriculture and aquaculture, epidemiology } \\
\text { of other diseases, vaccination }\end{array}$ \\
\hline Legislative (L) & $\begin{array}{l}\text { Mechanisms to support policy including the implementation of relevant } \\
\text { legislation and effectiveness of this approach }\end{array}$ & $\begin{array}{l}\text { Administrative power of health and social care } \\
\text { organisations, travel restriction }\end{array}$ \\
\hline Industry (I) & $\begin{array}{l}\text { Wider industry in addition to technologies, such as pharmaceutics, } \\
\text { investments in the health care industry, pluralistic health care (government } \\
\text { and private share) and role of health care insurers }\end{array}$ & $\begin{array}{l}\text { Workforce, medical resources, insurance, research } \\
\text { and development (R\&D) }\end{array}$ \\
\hline
\end{tabular}

PESTELI - Political, Economic, Sociological, Technological, Ecological, Legislative, Industry

\section{METHODS}

We conducted a literature review to identify 1) situation analyses in pandemic management, and 2) studies which examined contextual factors influencing pandemic management. In this study, we defined 'pandemic' as an infectious disease outbreak that has spread across multiple continents or worldwide, affecting a large population $[12,13]$.

\section{Study eligibility}

Any study published in English from 01 January 2000 to 01 June 2020 that has 1) performed a situation analysis to assess the environment for pandemic management, or 2) examined macro-level contextual determinants influencing pandemic management of one or more of the following pandemics: Severe Acute Respiratory Syndrome (SARS), Middle East Respiratory Syndrome (MERS), COVID-19, Influenza A (H1N1), Ebola virus disease, and Zika virus disease, were considered in this review, in any country(ies) setting(s). The PICO (Population, Intervention, Comparison and Outcomes) [14] and SPIDER (Sample, Phenomenon of interest, Design, Evaluation, Research type) inclusion and exclusion criteria were applied at the review stages [15]. Studies focussing solely on other infectious diseases (eg, tuberculosis, malaria, HIV/AIDS, cholera, dengue), non-communicable conditions (eg, obesity, diabetes, Alzheimer disease, substance misuse), or local outbreaks (eg, a Methicillin-resistant Staphylococcus aureus outbreak in one hospital) were excluded. 


\section{Search strategy and information sources}

The methods used in this review are in line with the PRISMA extension for scoping reviews (PRISMA-ScR) guidelines [16]. The protocol is available from the authors upon request. The PRISMA-ScR checklist was completed to guide study selection and data extraction. We restricted the search period from January 2000 onwards to capture major pandemics. We limited the language to English. We searched PubMed, Ovid MEDLINE, Ovid EMBASE, Global Health, Health Management, and the Cochrane Library databases. Searches included both controlled vocabulary (pre-defined subheadings) (eg, Pandemics) and text words (eg, strategic analysis). The search strings used are provided in Appendix S1 of the Online Supplementary Document.

\section{Study selection}

The title and abstract of the studies yielded from the database and reference list search were randomly assigned into two groups. Three researchers (NZ, RA, HK) participated in the title and abstract screening and in each group, by rotation, one pair independently reviewed each title and abstract and the third researcher resolved the disagreements in decisions (Group 1 - RA, Group 2 - HK). Two researchers (NZ, HK) independently reviewed the full-text articles which passed the title and abstract screening. All discrepancies were discussed and re-examined by the third reviewer (RA) until agreement was reached.

\section{Assessment of study quality and risks of bias}

We excluded those studies where a full article was not available (eg, conference proceedings, meeting minutes). We excluded studies that did not include the sections in the preferred reporting items set out in the PRISMA-ScR checklist [16].

Table 2. Study design and PESTELI domains covered in individual studies

\begin{tabular}{|c|c|c|c|c|c|c|c|c|c|c|c|c|c|c|c|}
\hline \multirow{2}{*}{ STUDY } & \multicolumn{2}{|c|}{ STUDY CHARACTER } & \multicolumn{6}{|c|}{ STUDY DESIGN } & \multicolumn{7}{|c|}{ PESTELI DOMAINS } \\
\hline & Year & Setting & 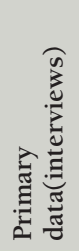 & 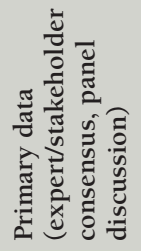 & 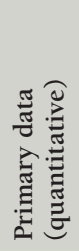 & 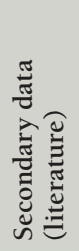 & 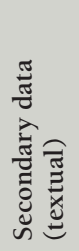 & 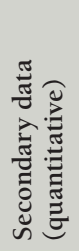 & $\mathbf{P}$ & Econ & $S$ & $\mathrm{~T}$ & E & $\mathrm{L}$ & I \\
\hline \multicolumn{16}{|c|}{ COVID-19 } \\
\hline$[21]$ & 2020 & Italy & & $*$ & & $*$ & $*$ & & EFR & & & EFR & & EF & $\mathrm{EF}$ \\
\hline [22] & 2020 & China & & & & & $*$ & $*$ & & & & EFR & & & EFR \\
\hline$[23]$ & 2020 & USA & & & * & & & & & & EFR & & & & \\
\hline \multicolumn{16}{|c|}{ Ebola virus disease } \\
\hline$[24]$ & 2020 & West Africa & & & & & $*$ & $*$ & $\mathrm{EF}$ & EF & EF & & EFR & EFR & $\mathrm{EF}$ \\
\hline [25] & 2016 & Sierra Leone & $*$ & & & & & $*$ & $\mathrm{~F}$ & $\mathrm{R}$ & EFR & FR & & & FR \\
\hline [26] & 2014 & Nigeria & & & & $*$ & & & FR & & EFR & $\mathrm{R}$ & & $\mathrm{F}$ & \\
\hline$[27]$ & 2018 & West Africa & & & & & $*$ & * & EF & $\mathrm{F}$ & $F$ & & & & $\mathrm{EF}$ \\
\hline \multicolumn{16}{|c|}{ Influenza A (H1N1) } \\
\hline$[28]$ & 2018 & Eastern Mediterranean & & $*$ & & & $*$ & & EFR & EF & $\mathrm{F}$ & EFR & $\mathrm{F}$ & EF & $\mathrm{EF}$ \\
\hline [29] & 2014 & Global & & & & $*$ & & & & & EFR & & & & \\
\hline [30] & 2010 & Asia & $*$ & & & & $*$ & * & EFR & EF & EF & $\mathrm{EF}$ & $\mathrm{EF}$ & & EFR \\
\hline [31] & 2018 & USA & & & * & & & & & & EFR & & & & \\
\hline [32] & 2016 & Global & & & & $*$ & & & & & $\mathrm{EF}$ & & & & \\
\hline [33] & 2014 & Global & & & & * & & & & & EFR & & & & \\
\hline [34] & 2012 & Global & & & & * & & & & & $\mathrm{EF}$ & & & & \\
\hline \multicolumn{16}{|c|}{ Multiple pandemics } \\
\hline$[35]$ & 2020 & Global & & & & $*$ & & & $\mathrm{EF}$ & $\mathrm{F}$ & EFR & FR & $\mathrm{F}$ & & $\mathrm{EF}$ \\
\hline [36] & 2020 & Global & & & & $*$ & & & $\mathrm{EF}$ & $\mathrm{F}$ & FR & FR & & & FR \\
\hline [37] & 2020 & Global & & & & $*$ & $*$ & $*$ & EFR & & $\mathrm{R}$ & EFR & EFR & $\mathrm{R}$ & $\mathrm{F}$ \\
\hline [38] & 2012 & Global & & & & $*$ & & & & & & EFR & EFR & & $\mathrm{R}$ \\
\hline [39] & 2020 & Global & & & & * & & & EFR & EF & EF & FR & $\mathrm{E}$ & & \\
\hline
\end{tabular}

PESTILE - Political, Economic, Sociological, Technological, Ecological, Legislative, Industry, E- examined, F - findings reported, R-recommendation proposed *Indicates types of data included in the study. 
Formal quality appraisal of the included individual studies was not performed, as this would be beyond the aim of this scoping review, which was to map key concepts, types of evidence, and gaps in research $[17,18]$. Evaluation of intervention and policy effectiveness is not the aim of the current review [19,20].

\section{Data extraction and analysis}

Three researchers (NZ, HK, RA) carried out data extraction, with cross-validation for 50\% of the studies using a standardised data extraction table (Microsoft Excel, Microsoft Inc, Seattle, WA, USA). We anticipated descriptive results given the qualitative nature of the studies. Key study characteristics, methods of data collection, situational analyses frameworks employed, and which of the PESTELI domains had been examined (E), findings reported on (F) and recommendations made (R) were extracted (Table 2). Factors influencing pandemic management into facilitators and inhibitors against the 7 domains were synthesised (Table 3-6).

\section{Ethics approval}

This study did not require ethics approval as is a literature review.

Table 3. Facilitators and inhibitors in pandemic management identified: COVID-19

\begin{tabular}{|c|c|c|c|c|}
\hline POLITICAL (P) & ECONOMIC (ECON) SOCIOLOGICAL (S) & TECHNOLOGICAL (T) & LEGISLATIVE (L) & INDUSTRY (I) \\
\hline \multicolumn{5}{|l|}{ COVID-19: } \\
\hline \multicolumn{5}{|l|}{ Facilitators } \\
\hline $\begin{array}{l}\text { Enactment of emer- } \\
\text { gency policies and } \\
\text { decrees (Italy) [21] }\end{array}$ & & $\begin{array}{l}\text { Health informat- } \\
\text { ics technologies (eg, } \\
\text { big data for tracking } \\
\text { and tracing; } 5 \mathrm{G} \text { net- } \\
\text { work for telemed- } \\
\text { icine; artificial in- } \\
\text { telligence for rapid, } \\
\text { precise diagnostics); } \\
\text { regulation of travel- } \\
\text { ling using QR code } \\
\text { of health record } \\
\text { (China) [22] }\end{array}$ & $\begin{array}{l}\text { Banned air traffic } \\
\text { from China; man- } \\
\text { datory reporting } \\
\text { of travel history to } \\
\text { the Italian Nation- } \\
\text { al Health Service } \\
\text { (SSN); mandato- } \\
\text { ry quarantine (Ita- } \\
\text { ly) [21] }\end{array}$ & $\begin{array}{l}\text { Rapid response in- } \\
\text { cluding increased } \\
\text { health care human } \\
\text { resources capacity } \\
\text { and protected sup- } \\
\text { ply chains (Italy) } \\
\text { [21]; }\end{array}$ \\
\hline
\end{tabular}

\begin{tabular}{|c|c|c|}
\hline \multirow[t]{2}{*}{$\begin{array}{l}\text { Inconsistency be- } \\
\text { tween local and na- } \\
\text { tional guidance in } \\
\text { technical orders and } \\
\text { clinical protocols } \\
\text { (Italy) [21] }\end{array}$} & $\begin{array}{l}\text { Lack of public } \\
\text { knowledge result- } \\
\text { ed in continuation } \\
\text { of mass gatherings } \\
\text { (US) [23] }\end{array}$ & $\begin{array}{l}\text { Constraints in data } \\
\text { integration and } \\
\text { smart technologies } \\
\text { to support contact } \\
\text { tracing, surveillance, } \\
\text { and other interven- } \\
\text { tions (Italy) [21] }\end{array}$ \\
\hline & & $\begin{array}{l}\text { Lack of rapid de- } \\
\text { ployment of infor- } \\
\text { mation systems; } \\
\text { suboptimal infor- } \\
\text { mation exchange } \\
\text { across heath insti- } \\
\text { tutions; non-stan- } \\
\text { dardised electron- } \\
\text { ic health records to } \\
\text { streamline emer- } \\
\text { gency information } \\
\text { (China) [22] }\end{array}$ \\
\hline
\end{tabular}


Table 4. Facilitators and inhibitors in pandemic management identified: Ebola

\begin{tabular}{|c|c|c|c|c|c|}
\hline POLITICAL (P) & ECONOMIC (ECON) & TECHNOLOGICAL (T) & ECOLOGICAL (E) & LEGISLATIVE (L) & INDUSTRY (I) \\
\hline \multicolumn{6}{|l|}{ Ebola: } \\
\hline \multicolumn{6}{|l|}{ Facilitators } \\
\hline $\begin{array}{l}\text { Political commitment con- } \\
\text { tributed to a rapid/effective } \\
\text { response in some countries } \\
\text { (eg, Nigeria) (West Africa) } \\
\text { [24] }\end{array}$ & $\begin{array}{l}\text { Countries with trading part- } \\
\text { ners are more likely to act } \\
\text { early to protect trade and } \\
\text { prevent contagion; secur- } \\
\text { ing important inputs for do- } \\
\text { mestic industries or output } \\
\text { markets motivate HCW de- } \\
\text { ployment abroad (West Af- } \\
\text { rica) [27] }\end{array}$ & $\begin{array}{l}\text { Hand shaking discouraged by the } \\
\text { federal government; HCWs and } \\
\text { non-clinical staff in hospitals de- } \\
\text { manding full PPE before consulting } \\
\text { any patient; high public awareness } \\
\text { and interest; trust and confidence in } \\
\text { public authorities enhancing adop- } \\
\text { tion of recommended containment } \\
\text { measures (Nigeria) [26] }\end{array}$ & & $\begin{array}{l}\text { Temporary border closure } \\
\text { (eg, Cameroon and Chad) } \\
\text { (Nigeria) [26] }\end{array}$ & \\
\hline \multicolumn{6}{|l|}{$\begin{array}{l}\text { Declaration of national emer- } \\
\text { gency (eg, Nigeria); demon- } \\
\text { stration of political com- } \\
\text { mitment (eg, Presidential } \\
\text { Summit attended by Minister } \\
\text { of Health, State Governors } \\
\text { and their Commissioners } \\
\text { in Nigeria); national weekly } \\
\text { briefings to provide up-to- } \\
\text { date information, and dispel } \\
\text { fears, rumours and miscon- } \\
\text { ceptions (Nigeria) [26] }\end{array}$} \\
\hline $\begin{array}{l}\text { Deployment of foreign } \\
\text { HCWs, as aids from allies, } \\
\text { maintain global balance of } \\
\text { political power; historical } \\
\text { choices and policies facilitate } \\
\text { institutionalised capacities } \\
\text { and norms for civil emer- } \\
\text { gency management, foreign } \\
\text { medical aid, or overseas mil- } \\
\text { itary personnel deployments } \\
\text { (West Africa) [27] }\end{array}$ & & $\begin{array}{l}\text { Media coverage and public attention } \\
\text { facilitate humanitarian assistance } \\
\text { and HCW deployment (West Afri- } \\
\text { ca) }[27]\end{array}$ & & & \\
\hline
\end{tabular}


Poor health care system ficontact tracer recruitment and organisation led by nonnancing (West Africa) [24] health institutes) (Sierra Leone) (23)
Inadequate self-prescribed infection Incomplete case monitoring database (Sier-

pealth education; poor housing con- ra Leone) [25]

ditions in rural areas; poor safety

orientation (training) in hospitals;

low adherence to government regu-

lations in rural areas despite public

campaigns; re-infection due to risky

sexual behaviours; lack of follow-up

with recovered cases and long-term

monitoring; culture and tradition

(eg, mass gathering at funerals)

(West Africa) [24]

Contests between powerful

domestic actors delaying cri-

sis response; organisational

limitations, cognitive barriers

and political construction of

threat perception in policy

makers may lead to hesita-

tion in HCW deployment

(West Africa) [27]
Rejecting contact tracing due to stig-

ma and fear, and/or to avoid quaran-

tine; inadequate training of contact

tracers; lack of support to quaran-

tined citizens (Sierra Leone) [25]
High prevalence of nosoco- Cross-border transmission

mial infections; climate con-

ditions increasing transmis-

sion; deforestation; physical

proximity between human

and wildlife, including ani-

mal reservoirs (eg, fruit bats);

zoonotic pathogens trans-

mitting across species; low

vaccination due to misinfor-

mation in mass media (West

Africa) [24] due to relaxed immigration

policies (West Africa) [24]

Inadequate drug and PPE

supply; staffing limitation

due to transmission among

HCWs (West Africa) [24]

Stigma and discrimination against

patients and HCWs who treated

them and subsequent actions (eg,

protests near treatment centres due

to lack of knowledge, fear, and mis-

information on mass media (eg, Eb-

ola infection is incurable); low will-

ingness among HCWs to join the

front line due to fear: low confidence

in the capacity of health system and

leadership to provide reliable infor-

mation and resources for infection

prevention (Nigeria) [26] 
Table 5. Facilitators and inhibitors in pandemic management identified: Influenza A (H1N1)

\begin{tabular}{|c|c|c|c|c|c|}
\hline POLITICAL (P) & ECONOMIC (ECON) & SOCIOLOGICAL (S) & TECHNOLOGICAL (T) & ECOLOGICAL (E) & INDUSTRY (I) \\
\hline \multicolumn{6}{|l|}{ Influenza A (H1N1): } \\
\hline \multicolumn{6}{|l|}{ Facilitators } \\
\hline \multirow[t]{4}{*}{$\begin{array}{l}\text { Arrangement and strength in } \\
\text { governance and stewardship } \\
\text { (Asia) [30] }\end{array}$} & $\begin{array}{l}\text { External funds through } \\
\text { the Partnership } \\
\text { Contribution (PC) of } \\
\text { Pandemic Influenza } \\
\text { Preparedness (PIP) } \\
\text { (Eastern Mediterranean) } \\
\text { [28] }\end{array}$ & $\begin{array}{l}\text { Public knowledge (eg, knowledge in } \\
\text { transmission mechanism, infection control } \\
\text { measures; efficacy and effectiveness of control } \\
\text { measures); optimal perception of severity and } \\
\text { vulnerability of the infection (Global) [29] }\end{array}$ & $\begin{array}{l}\text { Technologies available } \\
\text { for surveillance, } \\
\text { case detection, and } \\
\text { infection control } \\
\text { (Asia) [30] }\end{array}$ & $\begin{array}{l}\text { Vaccination coverage; } \\
\text { early initiation of antivirals } \\
\text { (Eastern Mediterranean) [28] }\end{array}$ & $\begin{array}{l}\text { External resources available } \\
\text { for LMICS (eg, Laos, } \\
\text { Cambodia) (Asia) (31) }\end{array}$ \\
\hline & & $\begin{array}{l}\text { Optimal knowledge in the influenza pandemic; } \\
\text { having a health-related personal network (eg, } \\
\text { having family or friends who can provide } \\
\text { health-related information or support) (US) } \\
\text { [31] }\end{array}$ & & $\begin{array}{l}\text { Existing epidemiological } \\
\text { profile of high life expectancy } \\
\text { and low mortality (Asia) [30] }\end{array}$ & \\
\hline & & $\begin{array}{l}\text { Adherence with antiviral medication (either } \\
\text { as prophylaxis or treatment) associated with } \\
\text { previous compliance with other precautionary } \\
\text { advice about pandemic flu, beliefs that the } \\
\text { recommended preventive measures were } \\
\text { necessary; having discussed the option of } \\
\text { taking antiviral medication with someone who } \\
\text { had not experienced side effects (Global) [32] }\end{array}$ & & & \\
\hline & & $\begin{array}{l}\text { Perception of benefits of vaccination (eg, } \\
\text { protecting themselves and loved ones, } \\
\text { protecting patients); adequate perception of } \\
\text { susceptibility (eg, risk of infection, immunity } \\
\text { via previous exposure) and severity; responsive } \\
\text { action to information from mass media, public } \\
\text { health authorities, and coworkers/supervisor } \\
\text { (Global) [34] }\end{array}$ & & & \\
\hline
\end{tabular}


Table 5. Continued

\section{POLITICAL (P)}

Inhibitors

\section{Inadequate preparedness}

plans lacking detailed

strategic review and

assessment (Eastern

Mediterranean) [28]

\section{ECONOMIC (ECON)}

SOCIOLOGICAL (S)

Insufficient budget for pandemic preparedness; reliance on external

funding (Asia) [30]
The annual Islamic pilgrimage (Haji) driving transmission; population displacement and migration due to ongoing wars and conflicts (Eastern Mediterranean) [28]

pealic heation specifilly

for Influenza A (instead focusing on Avian

influenza) (Asia) [30]

Low education; unemployment and low socio-

economic position associated with inadequate access to health information (US) [31]

Non-adherence with antiviral medication due

to experienced or perceived adverse effects, not

wanting to take medication, forgetting, losing,

or running out of tablets (Global) [32]

Social stigma and discrimination against one

or more particular social sub-group (s); lack

of trust in government's capacity and fairness

when handling the emergence; inequalities

in exposure to public health communication

messages which led to negative outcomes

including low vaccine uptake; inadequate

knowledge, attitude, and beliefs about the

pandemic; suboptimal care seeking behaviour;

low ability and willingness to seek and process

information; poor emotional responses (Global)

[33]

Vaccine hesitancy among HCWs due to

concerns in vaccine safety, adverse effects,

effectiveness/efficacy) (Global) [34] 
Table 6. Facilitators and inhibitors in pandemic management identified: multiple pandemics

\begin{tabular}{|c|c|c|c|c|c|}
\hline POLITICAL (P) & EсоNOMIC (ECON) & SOCIOLOGICAL (S) & TECHNOLOGICAL (T) & ECOLOGICAL (E) & INDUSTRY (I) \\
\hline \multicolumn{6}{|l|}{ Multiple pandemics: } \\
\hline \multicolumn{6}{|l|}{ Facilitators } \\
\hline $\begin{array}{l}\text { Policies to define Community } \\
\text { Health Worker (CHW) } \\
\text { tasks and roles; stakeholder } \\
\text { engagement in governance } \\
\text { arrangements (Global) [35] }\end{array}$ & & $\begin{array}{l}\text { Appropriate CHW } \\
\text { training; organised and } \\
\text { funded well-being support } \\
\text { to CHWs; community } \\
\text { engagement to enhance } \\
\text { social mobilisation, build } \\
\text { trust and increase service } \\
\text { utilisation; transparency in } \\
\text { communication mitigated } \\
\text { fears (Global) [35] }\end{array}$ & $\begin{array}{l}\text { Information management } \\
\text { systems and digital health } \\
\text { technology employed for } \\
\text { CHW programmes (Global) } \\
\text { [35] }\end{array}$ & $\begin{array}{l}\text { Improved vaccination } \\
\text { coverage with as an } \\
\text { outcome of CHWs' regular } \\
\text { household visits, liaising with } \\
\text { poultry and feed sellers at } \\
\text { marketplace (Global) [35] }\end{array}$ & $\begin{array}{l}\text { Adequate PPE supply to } \\
\text { CHWs (Global) [35] }\end{array}$ \\
\hline $\begin{array}{l}\text { Collaboration between } \\
\text { governmental agencies and } \\
\text { external organisations (eg, } \\
\text { the CDC and WHO) (Global) } \\
\text { [37] }\end{array}$ & $\begin{array}{l}\text { Sustained investment } \\
\text { in CHWs (eg, financial } \\
\text { incentives remote area } \\
\text { allowance, performance- } \\
\text { based financing payments or } \\
\text { accommodation); additional } \\
\text { resources to support the well- } \\
\text { being of CHWs during and } \\
\text { post pandemic (Global) [35] }\end{array}$ & $\begin{array}{l}\text { Community palliative care } \\
\text { to support people who } \\
\text { prefer to remain at home } \\
\text { towards end of life; re- } \\
\text { deployment of volunteers } \\
\text { to provide psychosocial and } \\
\text { bereavement care; support } \\
\text { carers to deal with stress; } \\
\text { communication and leader } \\
\text { identification in environment } \\
\text { with multiple caregivers, } \\
\text { especially in low resource } \\
\text { settings (Global) [36] }\end{array}$ & $\begin{array}{l}\text { Volunteers transitioned to } \\
\text { become virtually deployed } \\
\text { (Global) [36] }\end{array}$ & & \\
\hline
\end{tabular}


Table 6. Continued

\begin{tabular}{|c|c|c|c|c|c|}
\hline POLITICAL (P) & ECONOMIC (ECON) & SOCIOLOGICAL (S) & TECHNOLOGICAL (T) & ECOLOGICAL (E) & INDUSTRY (I) \\
\hline $\begin{array}{l}\text { Credibility of evidence } \\
\text { informing responses; health } \\
\text { care system capacity (Global) } \\
\text { [39] }\end{array}$ & & & $\begin{array}{l}\text { Pathogen discovery } \\
\text { techniques; meta-genomic } \\
\text { technology to predict } \\
\text { pandemic potential in novel } \\
\text { microbes (Global) [38] }\end{array}$ & & \\
\hline \multicolumn{6}{|l|}{ Inhibitors } \\
\hline $\begin{array}{l}\text { Lack of a prior pandemic } \\
\text { communication plan (Global) } \\
\text { [35] }\end{array}$ & $\begin{array}{l}\text { Ethical challenges concerning } \\
\text { allocation of scare resources } \\
\text { (Global) [36] }\end{array}$ & $\begin{array}{l}\text { Globalisation accelerating } \\
\text { transmission; culture (eg, } \\
\text { traditional burial practices, } \\
\text { dietary habits such as } \\
\text { consumption of bush meat, } \\
\text { blaming and social stigma) } \\
\text { (Global) [39] }\end{array}$ & $\begin{array}{l}\text { Non-functional surveillance } \\
\text { systems due to delayed } \\
\text { reporting from health } \\
\text { facilities; contact tracing } \\
\text { potentially hamper primary } \\
\text { service delivery (Global) [35] }\end{array}$ & $\begin{array}{l}\text { Fast transmission due to } \\
\text { environmental change and } \\
\text { international travel via rail } \\
\text { and air (Global) [37] }\end{array}$ & $\begin{array}{l}\text { Disruption in drug and } \\
\text { equipment supplies common } \\
\text { during pandemics; lack of } \\
\text { research in equity, gender } \\
\text { equality, and economic } \\
\text { evaluation of CHW } \\
\text { programmes (Global) [35] }\end{array}$ \\
\hline $\begin{array}{l}\text { Delayed, poor coordination } \\
\text { of hospital level policies } \\
\text { and protocols and hospice- } \\
\text { specific guidance (Global) } \\
\text { [36] }\end{array}$ & $\begin{array}{l}\text { Economic inequalities in } \\
\text { social sub-group(s) (Global) } \\
\text { [39] }\end{array}$ & & $\begin{array}{l}\text { Lack of data collection } \\
\text { systems to understand } \\
\text { patient outcomes and share } \\
\text { learnings (Global) [36] }\end{array}$ & & $\begin{array}{l}\text { Lack of material supplies } \\
\text { (eg, PPE, diagnostic and } \\
\text { monitoring equipment) } \\
\text { (Global) [36] }\end{array}$ \\
\hline $\begin{array}{l}\text { Confusion in attribution of } \\
\text { responsibility (eg, health } \\
\text { care system or the general } \\
\text { public); lack of coordination } \\
\text { in responses among agencies } \\
\text { due to competing causal } \\
\text { explanations of the pandemic } \\
\text { and conflicts in priorities } \\
\text { (Global) [39] }\end{array}$ & & & $\begin{array}{l}\text { Low adoption of remote } \\
\text { medical assistance to } \\
\text { detect and control zoonotic } \\
\text { infectious disease outbreaks } \\
\text { (Global) [37] }\end{array}$ & $\begin{array}{l}\text { Juxtaposition of livestock } \\
\text { production and wildlife } \\
\text { populations; change in land } \\
\text { use related to development } \\
\text { and deforestation (Global) } \\
\text { [38] }\end{array}$ & $\begin{array}{l}\text { Lack of integration of internet } \\
\text { and related technologies for } \\
\text { surveillance activities (eg, } \\
\text { simultaneous reporting and } \\
\text { monitoring, end-to-end } \\
\text { connectivity, data assortment } \\
\text { and analysis, tracking and } \\
\text { alerts) (Global) [37] }\end{array}$ \\
\hline
\end{tabular}

\author{
Inadequate case reporting \\ due to lack of information \\ technologies (Global) [39]
}

*[35]: Lassa, Ebola, Influenza (H1N1, H5N1); [36]: Ebola, SARS, COVID-19, Influenza (H1N1); [37]: SARS, MERS, COVID-19; [38]: HIV/AIDS, SARS, Influenza (H1N1); [39]: SARS, Zika, Ebola. 
Figure 1. Study flowchart.

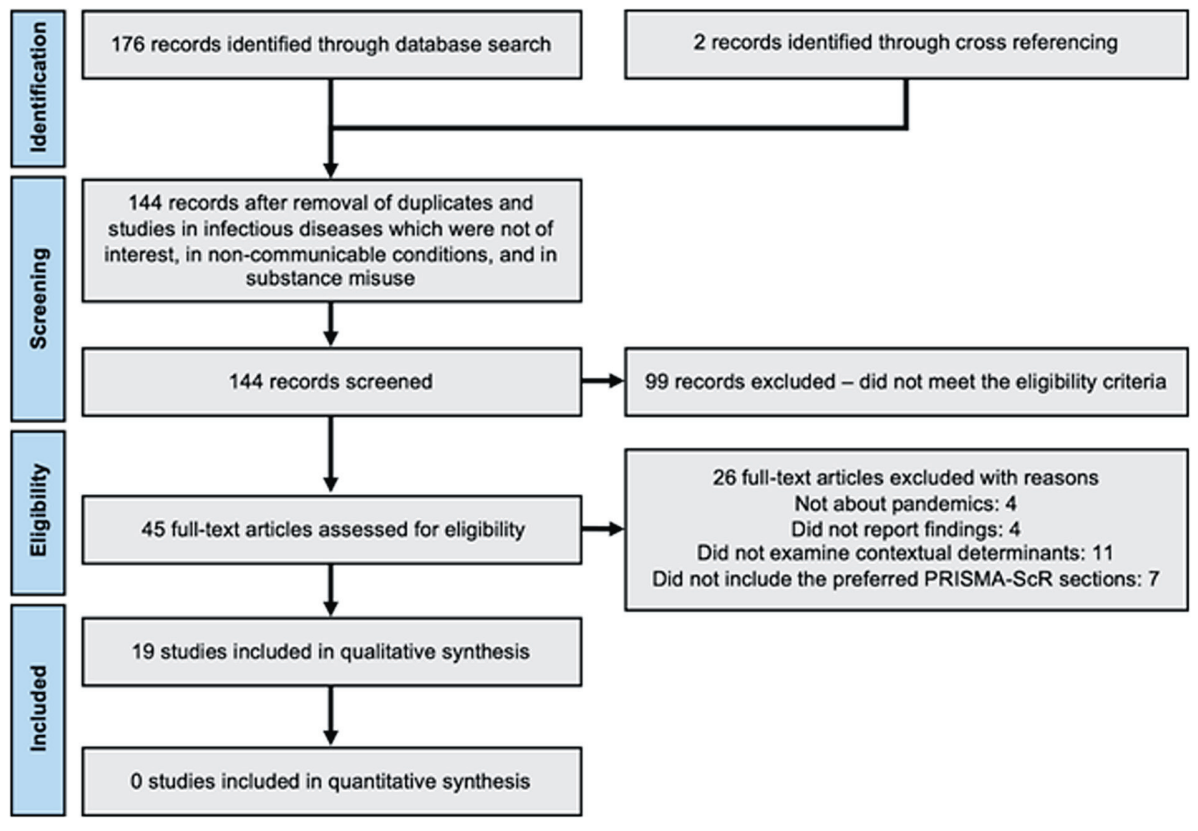

\section{RESULTS}

\section{Included studies}

A total of 176 studies were identified from the primary electronic databases. Two further studies were identified through a search of reference lists. After removal of duplicates and studies in diseases not of interest, a total of 144 records remained for screening. 45 studies were eligible for full text review and 26 studies were excluded with reasons, yielding 19 studies that met the inclusion criteria. Figure 1 summarizes the flow of literature search and screening.

\section{Study characteristics}

Of the included studies, 6 were single country analyses [21$23,25,26,31]$, and 13 were regional level multi-country studies [24,27-30,32-39]. Fourteen studies had a single disease focus, with 3 studies on COVID-19 [21-23], 4 studies on Ebola virus disease [24-27], and 7 studies on Influenza A [28-34]. Five studies evaluated responses to one or more of COVID-19, SARS, MERS, Influenza A (H1N1), Ebola virus disease, and Zika virus disease pandemics [35-39].

No study included in this review explicitly set out to employ the PESTELI framework, but 3 studies employed alternative frameworks, including the SWOT (Strengths, Weaknesses, Opportunities, and Threat) framework [21], the PIP (Pandemic Influenza Preparedness) framework [28], and the SYSRA (Systemic Rapid Assessment) framework [30]. The other 16 studies examined macro-level determinants affecting the response and ability to manage the pandemic, including workforce mobilisation and deployment; adherence of vaccination and antiviral therapy; public knowledge, awareness, and perception; and compliance of non-pharmaceutical interventions. All studies were published after pandemic emergence. The timeline of the pandemics against the publication of the included studies (Figure 2), shows a notable gap for SARS and Zika.

Most of the studies employed one method of data collection: 9 reviews of the published academic literature [26,32-36,38-40] and $2[23,31]$ used primary data through population survey surveys.

Four studies $[21,25,28,30]$ used primary data via interviews or panel discussion with experts and stakeholders as well as secondary data collected through review of literature or other textual sources.

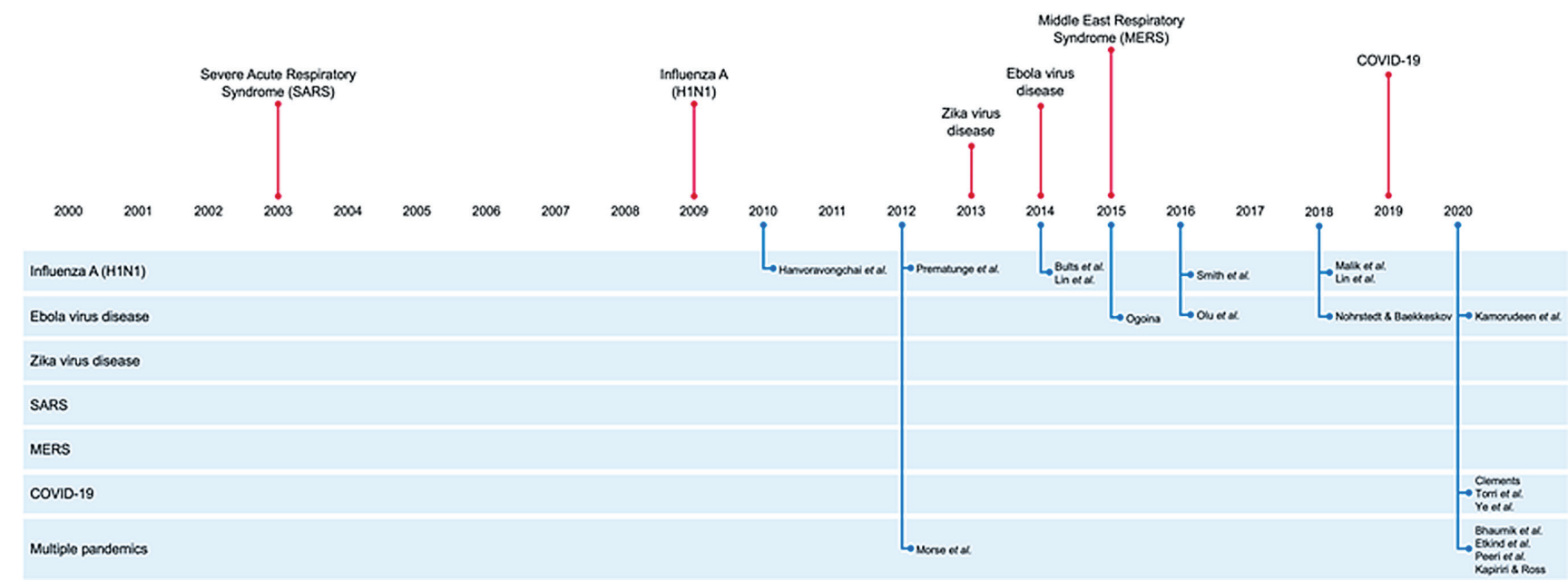

Figure 2. Pandemic and study publication timeline. 
Ten studies were results of work by researchers from a single country $[21-23,26,29,32-34,36,39]$. Nine studies were outcomes of international collaborations, where all corresponding authors of these international study groups were from high income countries bar 1 [24,25,27,28,30,31,35,37,38]. Two studies involved co-operation between research institutes and international agencies (ie, WHO and UN) $[25,28]$. Two studies had co-authors from national and local health authorities [21,25]. One study bridged research institutes, national and local health authorities, and the private sector [37].

\section{Analysis using the PESTELI framework}

Though the PESTELI framework was not utilised, one study reported findings in each of the domains [28]. Most studies (16) included analysis of the sociological domain. Notable gaps are evident in the legislative (14 studies), ecological (12 studies) and economic (11 studies) domain. While the political domain features in 11 studies $[21,24-28,30,35-37,39]$ only five of these make recommendations in this domain.

Political facilitators influencing the response included demonstration of political commitment $[21,24,26]$, and strength in governance and stewardship [30]. Inhibitors within the political domain emanated from lack of coordination between central and local governments and inadequate preparedness plans $(21,36)$; discord about which experts and institutes should lead [25] and the extent of inclusivity of stakeholders [35].

Under economic factors, international aid and external funds were a facilitator $(29,29)$ but over reliance on external funding was also reported as a barrier [30]. Level of health system financing was an inhibitor [24,30] and facilitator depending on country context, particularly in regards to sustained community health worker investment and enhanced support during pandemics in the case of Ebola in Uganda and Sierra Leone [35].

Sociological facilitators were high media coverage and maintaining public attention [27]; professional training of staff in health care and social care organisations [35]; and social support to citizens in isolation [36]. Conversely, the most frequently reported sociological inhibitors include lack of public knowledge and public health education in infectious disease prevention [23,26,30,31]; stigma and discrimination against infected patients and health care professionals involved in direct patient care $[25,26,33,39]$; cultural, traditional, and/ or religious practices that may over-ride guidance and health protection messages $[24,28,39]$. Perceived low risk of infection threat and the low value of infection preventive measures [32,34], and, diametrically opposite, anxiety and fear [26,29], also hindered progress. Lack of trust and confidence in authorities and abilities of the health care system to cope affected health-seeking behaviours [26,33]. Recommendations were proposed in 9 studies to address these sociological inhibitors, and some repeated from the first of these studies in 2014 to the latest in 2020. Recommendations include transparent communication between government and citizens to share information that is up-to-date, easy to interpret, and relevant to contexts (eg, tailored information for vulnerable groups) $[23,25,26,29,31,33,35-37]$.

Among the 7 studies, which included ecological analysis, 6 also analysed sociological factors $[24,28,30,35,37,39]$. The findings suggested that the drastic change in human lifestyle exerted an impact on ecological and environmental profiles, which then influenced human behaviour further. For instance, globalisation (S) and deforestation and climate change (E); dietary habits (S) and livestock production (E); population age distribution (S) and epidemiology profile (E); and international travel (S) and infection transmission (E). High vaccination coverage was the only ecological facilitator reported in 3 studies [28,30,35]. Ecological inhibitors were centred around human behaviour; contact/proximity with wild animals; transmission of zoonotic diseases through livestock production, and high levels of international travel $[24,28,37,38]$.

Among the 11 studies which assessed factors in the technological domain [21,22,25,26,28,30,35-39], existing information technologies did facilitate progress [22,30], but delayed deployment and limited utilisation of such technologies remained an inhibitor resulting in weak surveillance capacity $[21,22,25,28,35,36,39]$. In terms of the wider industry, internet coverage was cited as a facilitator [22] and inhibitor when coverage was low [37]. Industry inhibitors were an inadequate supply of personal protective equipment (PPE) and other medical resources $[24,25,27,35,36]$; and medical staff shortages $[24,25,28,30]$. As expected, the interdependence between the technological and industry domains is highlighted. Technologies reliant on uninterrupted power and network coverage are obvious examples, but also more basic equipment and supply-and-distribution chains rely on the existing wider industry or the ability to quickly scale up and deploy emergency provisions. Recommendations, including, for example, accelerated mobilisation of research and development $(R \& D)$ through incentives, were proposed to mitigate inhibitors in both technological and industry domains to enhance preparedness for future pandemics [22], but the timescales for this varied.

Overall, as noted above, the legislative domain was a gap in analyses and also was not explicitly assessed in the otherwise comprehensive assessment using the SYSRA framework of the Influenza A pandemic [30]. Five 
studies reported legislative facilitators [21,24,26,28,37] including travel bans and border closures [21,24,26]. The absence of legal frameworks for declaring an emergency and taking actions was cited as an inhibitor in the Eastern Mediterranean region [28].

\section{DISCUSSION}

Our findings appear to show missed opportunities for capture and synthesis of learning, based on a comprehensive analysis within and across pandemics. Wider and more timely dissemination of learning is needed. Large time delays between pandemic event and analysis are evident (see Figure 2). There are recommendations that had been made, from the relatively sparse set of studies, but which now appear again in the current pandemic as inhibitors across the 7 domains. This slow knowledge mobilisation has contributed to the apparent lack of preparedness in many countries for the current COVID-19 pandemic $[41,42]$. The vast range of outputs chosen for situational analyses could be interpreted as a signal that the endeavour is somehow seen as less scientific, or that the application of strategic management analyses in health has yet to mature. Public health journals have provided rapid turnaround on numerous opinion pieces which may have contributed to a disparate body of work lacking a common framework for synthesis. Additionally, this vacuum has left social media platforms as a fertile ground for debate on these macro-level influences [43]. We encourage a more robust and comparable approach. Additionally, data sources used for analyses are largely confined to secondary sources with only 6 studies employing primary and secondary or mixed methods approaches, which means that findings do not benefit from multi-disciplinary inquiry and the necessary data triangulation. While the PESTELI framework is designed to help draw out the influences specific to each domain, the approach also highlights the interconnections and complexity between the domains. The idea of interconnectivity is certainly not a new one when looking at health systems strengthening $[2,44]$. For example, inclusion of wider industry experts including project managers, data analysts, engineers, and experts in health systems and applied system methodologies must be coupled with the advocacy work and mobilisation of 'thought leaders' [2]. We have recently been urged to use this crisis as an opportunity to equip and strengthen the system. The role of social care in this wider definition of health systems needs to be made more explicit. This review unveiled the missed opportunity in integrating community-based care and collaborating with social care organisations in the previous Ebola pandemic and in high income countries in particular, in the current COVID-19 pandemic. The sector was not only underprepared but also inadequately supported, a concern raised well before the COVID-19 pandemic [45].

We acknowledge that limiting the study language has missed some national/local level studies but made this decision as the aim here was to look at potential for international learning. We encourage future analysis to include studies published in different languages and assess how the facilitators and inhibitors across the PESTELI domains might influence pandemic responses differently in world regions.

While this review was confined to the lessons from emergent pandemics since 2000, previous pandemics, notably HIV, provide us with key lessons about the importance of protecting the most vulnerable groups and the impressive economic gains when a global health coordinated perspective is taken. We need to capture the lessons which enabled that novel threat to be not only contained but also integrated in the planning of robust, holistic health and social care provision, with the political, sociological and technological domains working over time. Further within- and cross-domain analysis may be strengthened using established assessment tools, for example, the governance TAPIC (Transparency, Accountability, Participation, Integrity, Capacity) framework [46], building on previous work and enhancing comparability. The traditional use of such analysis in management sciences is then to guide a force-field analysis where strategies are formulated to either weaken the inhibitors or strengthen the facilitators whilst also explicitly acknowledging which factors are immutable for the short or medium term. Where political or economic barriers are unlikely to change (as evident by the lack of recommendations in these domains), these constraints are still useful when projecting potential impacts of the programmes with a sociological or technological focus, for example. As we learn and adjust to this novel pandemic we need to prepare for the short, medium and long-term and the framework suggested here can help with the required 360-degree view.

\section{CONCLUSIONS}

Ex-post analysis using the seven-domain strategic management framework provides further opportunities for a planned systematic response to pandemics which remains criticalas the current COVID-19 pandemic evolves. 


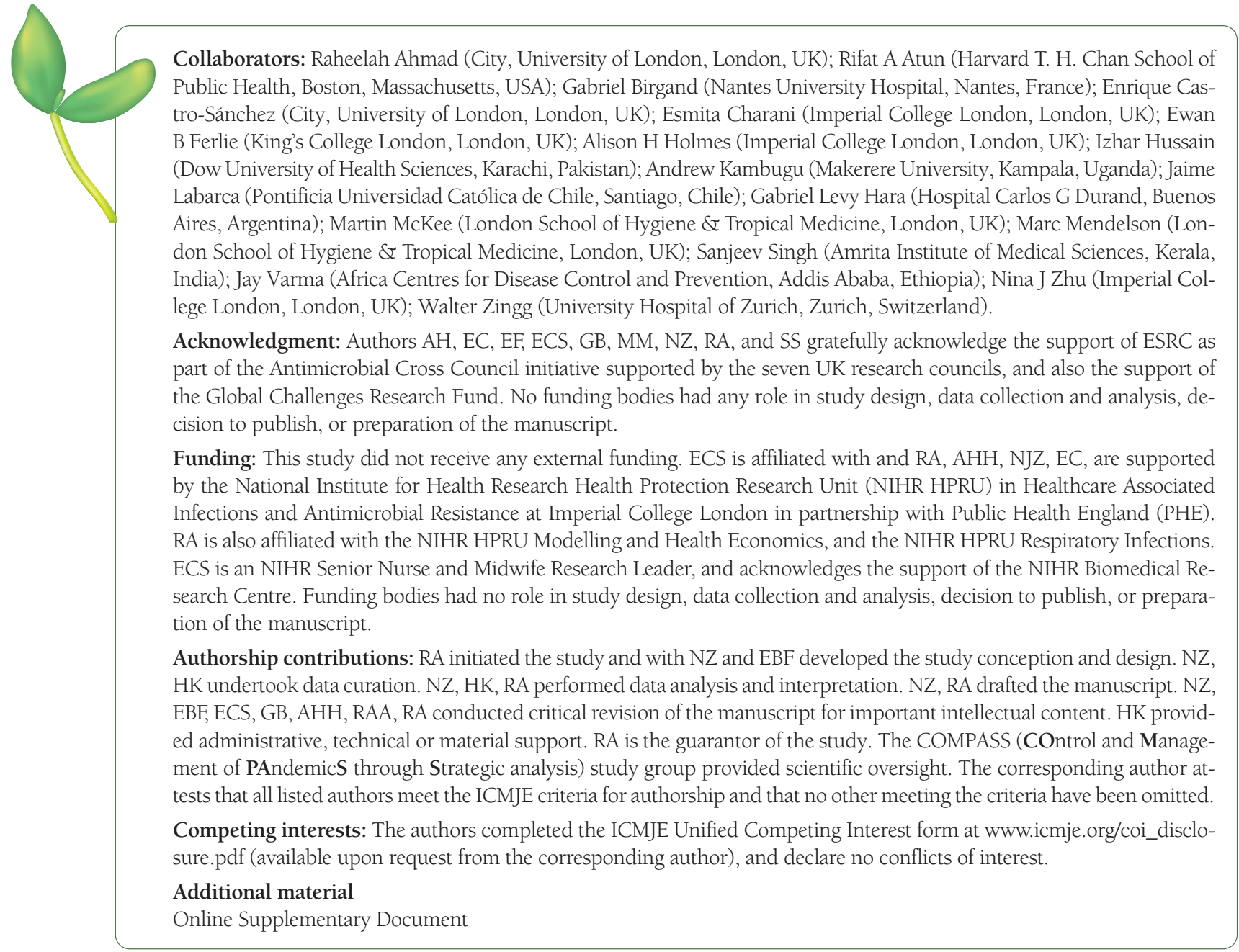

1 Forman R, Atun R, McKee M, Mossialos E. 12 Lessons learned from the management of the coronavirus pandemic. Health Policy. 2020;124:577-80. Medline:32425281 doi:10.1016/j.healthpol.2020.05.008

2 Durski KN, Osterholm M, Majumdar SS, Nilles E, Bausch DG, Atun R. Shifting the paradigm: Using disease outbreaks to build resilient health systems. BMJ Glob Health. 2020;5:e002499. Medline:32424013 doi:10.1136/bmjgh-2020-002499

3 World Health Organization. Situation analysis and priority setting. National health policies, strategies and plans. 2020. Available: https://www.who.int/nationalpolicies/processes/priorities/en/. Accessed: 20 May 2020.

4 Lewis H, Chaudry A, Ndow G, Crossey MM, Garside D, Njie R, et al. Ebola: is the response justified? Pan Afr Med J. $2015 ; 22$ Suppl 1:23. Medline:26740851 doi:10.11604/pamj.supp.2015.22.1.6598

5 Rotz LD, Hughes JM. Advances in detecting and responding to threats from bioterrorism and emerging infectious disease. Nat Med. 2004;10(12 Suppl):S130-6. Medline:15577931 doi:10.1038/nm1152

6 Khan K, McNabb SJN, Memish ZA, Eckhardt R, Hu W, Kossowsky D, et al. Infectious disease surveillance and modelling across geographic frontiers and scientific specialties. Lancet Infect Dis. 2012;12:222-30. Medline:22252149 doi:10.1016/ S1473-3099(11)70313-9

7 Schwartländer B, Stover J, Hallett T, Atun R, Avila C, Gouws E, et al. Towards an improved investment approach for an effective response to HIV/AIDS. Lancet. 2011;377:2031-41. Medline:21641026 doi:10.1016/S0140-6736(11)60702-2

8 Kavanagh MM, Singh R. Democracy, Capacity, and Coercion in Pandemic Response-COVID 19 in Comparative Political Perspective. J Health Polit Policy Law. 2020;45:997-1012. Medline:32464665 doi:10.1215/03616878-8641530

9 Kickbusch I, Leung GM, Bhutta ZA, Matsoso MP, Ihekweazu C, Abbasi K. Covid-19: How a virus is turning the world upside down. BMJ. 2020;369:m1336. Medline:32245802 doi:10.1136/bmj.m1336

10 Ahmad R, Zhu NJ, Leather AJM, Holmes A, Ferlie E. On behalf of the ASPIRES study co-investigators. Strengthening strategic management approaches to address antimicrobial resistance in global human health: A scoping review. BMJ Glob Health. 2019;4:e001730. Medline:31565417 doi:10.1136/bmjgh-2019-001730

11 Cameron M, Cranfield S, Iles V, Stone J. Managing Change in the NHS: Making informed decisions on change: key points for healthcare managers and professionals. Change. 2001. Available: https://westminsterresearch.westminster.ac.uk/item/93zq2/ making-informed-decisions-on-change-key-points-for-health-care-managers-and-professionals. Accessed: 20 May 2020.

12 Morens DM, Folkers GK, Fauci AS. What Is a Pandemic? J Infect Dis. 2009;200:1018-21. Medline:19712039 doi:10.1086/644537 
13 Grennan D. What Is a Pandemic? JAMA. 2019;321:910. Medline:30835310 doi:10.1001/jama.2019.0700

14 Cooke A, Smith D, Booth A. Beyond PICO: the SPIDER tool for qualitative evidence synthesis. Qual Health Res. 2012;22:143543. Medline:22829486 doi:10.1177/1049732312452938

15 Duggan J. Using System Dynamics and Multiple Objective Optimization to Support Policy Analysis for Complex Systems. Complex Decision Making. Berlin, Heidelberg: Springer; 2008

16 Tricco AC, Lillie E, Zarin W, O'Brien KK, Colquhoun H, Levac D, et al. PRISMA extension for scoping reviews (PRISMA-ScR): Checklist and explanation. Ann Intern Med. 2018;169:467-73. Medline:30178033 doi:10.7326/M18-0850

17 Pham MT, Rajić A, Greig JD, Sargeant JM, Papadopoulos A, McEwen SA. A scoping review of scoping reviews: advancing the approach and enhancing the consistency. Res Synth Methods. 2014;5:371. Medline:26052958 doi:10.1002/jrsm.1123

18 Colquhoun H. Current best practices for the conduct of scoping reviews. Impactful Biomedical Resaerch: Achieving Quality and Transparency. 2016. Available: https://www.equator-network.org/wp-content/uploads/2016/06/Gerstein-Library-scoping-reviews_May-12.pdf. Accessed: 20 May 2020.

19 Kastner M, Tricco AC, Soobiah C, Lillie E, Perrier L, Horsley T, et al. What is the most appropriate knowledge synthesis method to conduct a review? Protocol for a scoping review. BMC Med Res Methodol. 2012;12:114. Medline:22862833 doi:10.1186/1471-2288-12-114

20 Peters MDJ, Godfrey CM, Khalil H, McInerney P, Parker D, Soares CB. Guidance for conducting systematic scoping reviews. Int J Evid-Based Healthc. 2015;13:141-6. Medline:26134548 doi:10.1097/XEB.0000000000000050

21 Torri E, Sbrogiò LG, Di Rosa E, Cinquetti S, Francia F, Ferro A. Italian public health response to the COVID-19 pandemic: Case report from the field, insights and challenges for the department of prevention. Int J Environ Res Public Health. 2020;17:3666. Medline:32456072 doi:10.3390/ijerph17103666

22 Ye Q, Zhou J, Wu H. Using Information Technology to Manage the COVID-19 Pandemic: Development of a Technical Framework Based on Practical Experience in China. JMIR Med Inform. 2020;8:e19515. Medline:32479411 doi:10.2196/19515

23 Clements JM. Knowledge and behaviors toward COVID-19 among us residents during the early days of the pandemic: Cross-sectional online questionnaire. JMIR Public Health Surveill. 2020;6:e19161. Medline:32369759 doi:10.2196/19161

24 Kamorudeen RT, Adedokun KA. Ebola outbreak in West Africa, 2014 and 2016: Epidemic timeline, differential diagnoses, determining factors and lessons for future response. J Infect Public Health. 2020;13:956-62. Medline:32475805 doi:10.1016/j. jiph.2020.03.014

25 Olu OO, Lamunu M, Nanyunja M, Dafae F, Samba T, Sempiira N, et al. Contact Tracing during an Outbreak of Ebola Virus Disease in the Western Area Districts of Sierra Leone: Lessons for Future Ebola Outbreak Response. Front Public Health. 2016:4:130. Medline:27446896 doi:10.3389/fpubh.2016.00130

26 Ogoina D. Behavioural and emotional responses to the 2014 Ebola outbreak in Nigeria: A narrative review. Int Health. 2016;8:512. Medline:26678568

27 Nohrstedt D, Baekkeskov E. Political drivers of epidemic response: foreign healthcare workers and the 2014 Ebola outbreak. Disasters. 2018:42:41-61. Medline:28440550 doi:10.1111/disa.12238

28 Malik MR, Haq ZU, Saeed Q, Riley R, Khan WM. Distressed setting and profound challenges: Pandemic influenza preparedness plans in the Eastern Mediterranean Region. J Infect Public Health. 2018;11:352-6. Medline:29029975 doi:10.1016/j. jiph.2017.09.018

29 Bults M, Beaujean DJMA, Richardus JH, Voeten HACM. Perceptions and behavioral responses of the general public during the 2009 influenza A (H1N1) pandemic: A systematic review. Disaster Med Public Health Prep. 2015;9:207-19. Medline:25882127 doi:10.1017/dmp.2014.160

30 Hanvoravongchai P, Adisasmito W, Chau PN, Conseil A, De Sa J, Krumkamp R, et al. Pandemic influenza preparedness and health systems challenges in Asia: Results from rapid analyses in 6 Asian countries. BMC Public Health. 2010;10:322. Medline:20529345 doi:10.1186/1471-2458-10-322

31 Lin L, McCloud RF, Jung M, Viswanath K. Facing a Health Threat in a Complex Information Environment: A National Representative Survey Examining American Adults' Behavioral Responses to the 2009/2010 A(H1N1) Pandemic. Health Educ Behav. 2018;45:77-89. Medline:28548547 doi:10.1177/1090198117708011

32 Smith LE, D’Antoni D, Jain V, Pearce JM, Weinman J, Rubin GJ. A systematic review of factors affecting intended and actual adherence with antiviral medication as treatment or prophylaxis in seasonal and pandemic flu. Influenza Other Respir Viruses. 2016;10:462-78. Medline:27397480 doi:10.1111/irv.12406

33 Lin L, Savoia E, Agboola F, Viswanath K. What have we learned about communication inequalities during the H1N1 pandemic: A systematic review of the literature. BMC Public Health. 2014;14:484. Medline:24884634 doi:10.1186/1471-2458-14-484

34 Prematunge C, Corace K, McCarthy A, Nair RC, Pugsley R, Garber G. Factors influencing pandemic influenza vaccination of healthcare workers-A systematic review. Vaccine. 2012;30:4733-43. Medline:22643216 doi:10.1016/j.vaccine.2012.05.018

35 Bhaumik S, Moola S, Tyagi J, Nambiar D, Kakoti M. Community health workers for pandemic response: A rapid evidence synthesis. BMJ Glob Health. 2020;5:e002769. Medline:32522738 doi:10.1136/bmjgh-2020-002769

36 Etkind SN, Bone AE, Lovell N, Cripps RL, Harding R, Higginson IJ, et al. The Role and Response of Palliative Care and Hospice Services in Epidemics and Pandemics: A Rapid Review to Inform Practice During the COVID-19 Pandemic. J Pain Symptom Manage. 2020;60:e31-40. Medline:32278097 doi:10.1016/j.jpainsymman.2020.03.029

37 Peeri NC, Shrestha N, Rahman MS, Zaki R, Tan Z, Bibi S, et al. The SARS, MERS and novel coronavirus (COVID-19) epidemics, the newest and biggest global health threats: what lessons have we learned? Int J Epidemiol. 2020;49:717-26. Medline:32086938 doi:10.1093/ije/dyaa033

38 Morse SS, Mazet JAK, Woolhouse M, Parrish CR, Carroll D, Karesh WB, et al. Prediction and prevention of the next pandemic zoonosis. Lancet. 2012;380:1956-65. Medline:23200504 doi:10.1016/S0140-6736(12)61684-5 
39 Kapiriri L, Ross A. The Politics of Disease Epidemics: a Comparative Analysis of the SARS, Zika, and Ebola Outbreaks. Glob Soc Welf. 2020;7:33-45. Medline:32226719 doi:10.1007/s40609-018-0123-y

40 Atchison C, Bowman L, Vrinten C, Redd R, Pristera P, Eaton JW, et al. Perceptions and behavioural responses of the general public during the COVID-19 pandemic: A cross-sectional survey of UK Adults. medRxiv. 2020. Available: https://www.medrxiv.org/content/10.1101/2020.04.01.20050039v1. Accessed: 20 May 2020.

41 Bennet A, Bennet D, Fafard K, Fonda M, Lomond T, Messier L, et al. Knowledge mobilization in the social sciences and humanities: moving from research to action. Frost, West Virginia: MQI Press; 2007.

42 The Lancet. COVID-19: learning from experience. Lancet. 2020;395:1011. Medline:32222181 doi:10.1016/S01406736(20)30686-3

43 Galam S. Public debates driven by incomplete scientific data: The cases of evolution theory, global warming and H1N1 pandemic influenza. 2010. Available: https://arxiv.org/abs/1004.5009. Accessed: 20 May 2020.

44 Berwick DM. Choices for the "new Normal.". JAMA. 2020;323:2125-6. Medline:32364589 doi:10.1001/jama.2020.6949

45 Day M. Covid-19: Concern about social care's ability to cope with pandemics was raised two years ago. BMJ. 2020;369:m1879. Medline:32393505

46 Greer SL, Wismar M, Figueras J. Strengthening Health System Governance: Better Policies, Stronger Performance. World Health Organization. 2016. Available: https://www.euro.who.int/en/publications/abstracts/strengthening-health-system-governance-better-policies,-stronger-performance-2015. Accessed: 20 May 2020. 